\title{
Comparative study of coagulation effect of Diospyros Malabarica
}

\author{
N.S.Abegunasekara ${ }^{*}$, A.M.A.G.K.S.Bandara ${ }^{2}$ \\ ${ }^{1}$ GampahaWickramarachchi Ayurveda Institute, University of Kelaniya, Yakkala, Sri Lanka
}

\begin{abstract}
In most of the Ayurvedic remedies, Diospyros malabarica is used to obtain Rakthasthambana (coagulation) effect. The effect of leaves and stem bark extract of Diospyros malabarica on human blood coagulation was investigated using Lee and White method at Gampaha Wickramarachchi Ayurveda Institute in Sri Lanka. A total of 20 healthy individuals representing both sex were included in the study. For the test group, three tubes containing a volume of $0.5 \mathrm{~mL}$ of stem bark extract were allocated, and the sap was replaced with normal saline for the tubes of the control group. A volume of $1 \mathrm{~mL}$ of drawn blood was quickly added for every six tubes in situ, and all were incubated in a water bath at $37^{\circ} \mathrm{C}$. Every tube of two groups was observed carefully for a clot to measure the average clotting time of each group separately. Above procedure was repeated to all the fresh juice samples of stem bark and the leaves of Diospyros malabarica. The statistically significant reduction of average clotting time has proved that the stem bark of Diospyros malabarica and leaves of Diospyros malabarica have a highly significant effect on clotting cascade.

Key words: Rakthasthambana, Clotting time, Diospyros malabarica
\end{abstract}

\section{INTRODUCTION}

Diospyros malabarica is a typical Ayurvedic herb which can be used to treat many kinds of diseases in Ayurvedic aspects. And when it refers to the classical categorization; it is placed in Nyagrodadi Ghana in Susrutha Samhitha (Trikamji, 2002) and Caraka Samhitha (Trikamji, 2001) refers to Sandhaniya Ghana. Sandhaniya refers to many meanings in Ayurveda. Mainly it deals with hemostasis or Rakthasthambana. And it is the first method which is used in the coagulation pathway.

Rakthasthambana is a process which causes bleeding to stop, meaning to keep blood within a damaged blood vessel. And also it is the first stage of wound healing.

According to Ayurveda, hemostasis is done by Rakthastambana dravyas. They have a coagulating effect. It is due to their Kashaya Rasa (Astringent taste), Laghuguna (lightness), Rukshaguna (dryness), Sheethaveerya (cold in potency) and Katuvipaka (Pungent in biotransformation). Rakthasthambana dravyas are Madhuka (Madhucalongifolia), Madhuparni (Tinosporacordifolia), Prusniparni (Urariapicta), Ambasthaka, Samanga (Rubiacordifolia), Mocarasa (Bombaxceiba), Dhataki (Woodfordiafruticosa), Lodhra (Symplocosracemosa), Priyangu (Callicarpamacrophylla), Katphala (Myricanagi) (Moorthy, 2006).
These Rakthasthambana dravyas possessing Kashaya (Astringent), Madhura (Sweet), Tikta (Bitter) properties helps in wound healing. In addition to that, Thinduka is under the Nyagrodhadi Gana and Udardaprashamana Gana (Trikamji, 2001).

For further evaluation of Ayurvedic remedies, the drugs must be used in purposely. When a drug is being used, it must be proven the attributes or effectiveness of the drug. A drug cannot be used as it is. A scientifically proved language should be prioritized in the modern world. Ayurvedic medicine can be added some value by conducting such research-based evaluations.

There are a lot of formulations and remedies which could be found the Diospyros malabarica in the purpose of hemostatic effect. Even though it is categorized as a Rakthasthambana dravya in ancient Ayurvedic texts, the effect of it on blood coagulation hasn't proved. Therefore for better usage of this plant in a proper manner, this research was conducted to evaluate the actual coagulation effect of the Diospyros malabarica. And there are some differences in the coagulation effect of different plant parts. Ultimately it could be identified as the best plant part to be used in the purpose of Rakthasthambana.

\section{Corresponding author}

N.S.Abegunasekara

Email : nadeeabegunasekara@gmail.com, Phone: +94771579899

Received: $12-05-2019$ 
In the modern world, with the less availability of drugs, medical experts are searching for a single ingredient which has a similar remedial effect. There is a need for single ingredient on hemostatic purpose also.

In most of Ayurvedic remedies, Diospyros malabarica is used to obtain Rakthasthambana effect. Though Diospyros malabarica is used as a Rakthasthambana dravya, it has not been properly investigated and scientifically proven yet. This research will be an important preliminary study for introducing more drugs in hemostatic purpose, mainly in Shalya Tantra (Surgery) and also other aspects. Also, it will be helpful to find out the actual plant part of the Diospyros malabarica which causes the hemostatic effect.

Thinduka contains Kashayarasa, Laghu, Rukshaguna, Sheethaveerya and Katuvipaka properties. It has Kapha pitta shamaka dosha karma in action. Thinduka has Sthambana (Clotting) and Shothagna (Anti-inflamatory) action externally. Also, it contains Rakthasthambana, Rakthaprasadana (hemopoietic), Kaphagna, Muthrasangrahaniya (diuretic), Jwaragna (Anti-pyretic) actions internally (Trikamji, 2002).

Diospyros malabarica is a medium-sized tree that grows up to 15 meters in height. Leaves simple, alternate, or sub opposite, oblong-lanceolate, acute, or sometimes obtuse, glabrous, with prominent venation. Flowers unisexual, males in drooping cymes and female simple sessile. Fruits globose, yellow in ripe, with 4-8 compressed seeds. Fully ripe fruits have a mawkish sweet taste and are edible. The wood is grayish; close-grained, moderately hard and heavy is sometimes employed for building construction and in boat making. The wood yields charcoal. Pulped fruit is used as a preservative for fishing nets and as glue for bookbinding, boiled with or without powdered charcoal; it is used for paving bottoms of boats. Unripe fruits are employed for dyeing cloth and tanning hides. Bark used in dysentery and as febrifuge; unripe fruit used in ulcer; ripe fruit anti-calculus, used in diseases of blood; flower and fruit aphrodisiac, tonic, used in hiccup of children and lumbago; fruit and bark anti-dysenteric; ripe fruit and wood ant bilious, infusion of fruit used as a gargle in aphthae and sore throat; seed and bark astringent; seed oil used in dysentery and diarrhea. The bark, fruit, seed, and seed oil are used for treating boils, leucorrhoea, hemorrhage, polyuria, leprosy, urticarial, intermittent fever, and snakebite poisoning (Mondal et al., 2006).

The main objective of this research was to find out the coagulation effect of Diospyros malabarica. Specific objectives were to compare the coagulation effect of various plant parts of Diospyros malabarica, to find out best plant part, that contains coagulation effect, and to find out the average coagulation time.

\section{METHODOLOGY}

This research was carried out at the central laboratory of GampahaWickramarachchi Ayurveda Institute. A total of 10 females and 10 males were selected according to the inclusion and exclusion criteria. Blood samples were taken from each selected females and males. Coagulant effect of each plant part was determined by using the Lee-White (Test tube) method for fresh samples.

\section{Inclusion criteria}

- Age - Between 20-30 years old females and males.

- Amount of blood samples-20 samples (10 females and 10 males)

- Healthy females and males according to BMI

- BMI of females - $17-23 \mathrm{kgm}^{-2}$

- BMI of males - $20-25 \mathrm{kgm}^{-2}$

\section{Exclusion criteria}

- Age-Except between 20-30 years old females and males.

- BMI-Females-below 17 kgm-2 and above 23 kgm-2

- Males-below $20 \mathrm{kgm}-2$ and above $25 \mathrm{kgm}-2$

- Patients who used drugs such as antibiotics, antiviral, aspirin, heparin, Vitamin K, and corticosteroids within the last 4 weeks.

- Patients who are suffering from diseases like hypertension, diabetes mellitus, hemophilia, malaria, liver diseases, kidney diseases, various blood disorders like blood coagulation disorders.

\section{Lee and White Method}

- After cleaning the forearm, a venipuncture was made, and $6 \mathrm{~mL}$ of blood was drawn into a siliconsided glass or plastic syringe.

- The stopwatch was started at the same time.

- $1 \mathrm{~mL}$ blood was transferred each into three glass tubes and kept at $37^{\circ} \mathrm{C}$ in a water bath.

- The tubes were tilted after 3 minutes one by one for every 30 seconds.

- The clotting time was taken when the tubes were tilted without spilling of their contents.

- The average clotting time was calculated using three tubes.

\section{Materials:}

Parts of the Diospyros malabarica

Scale 01

Grinder 01

Measuring cylinder 01

A piece of pure clean Cotton cloth 
$5 \mathrm{ml}$ disposable Syringes 30

Micropipette 01

Beakers

Khan tubes 150

Stopwatch 01

Normal saline

\section{Methodology:}

Fresh, raw, and clean parts of Diospyros malabarica were collected from the Kurunegala district, and they were authenticated with the help of a botanist in the Gampaha Wickramarachchi Ayurveda Institute. The necessary materials/equipment were arranged.

Parts of Diospyros malabarica were cleaned well-using water and crushed separately. Then the crude extract was collected into a beaker using the pure, clean cotton cloth.

Twenty numbers of healthy persons aged around 25 years, representing both sexes were randomly selected from the Institute, and written consent was obtained for the study. Phlebotomy was done by a well-trained medical Laboratory Technician in the central laboratory under aseptic conditions.

Lee and White method, which is simple and accurate, was used to measure clotting time. For the blood of each individual, both test and control experiments were carried out at the same time.

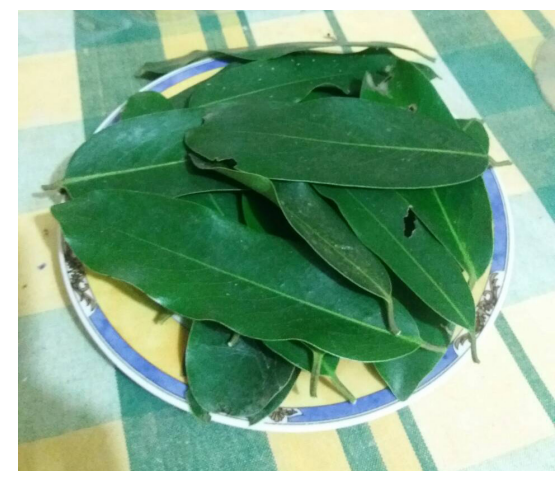

Figure 1: Leaves and stem bark of Diospyros malabarica
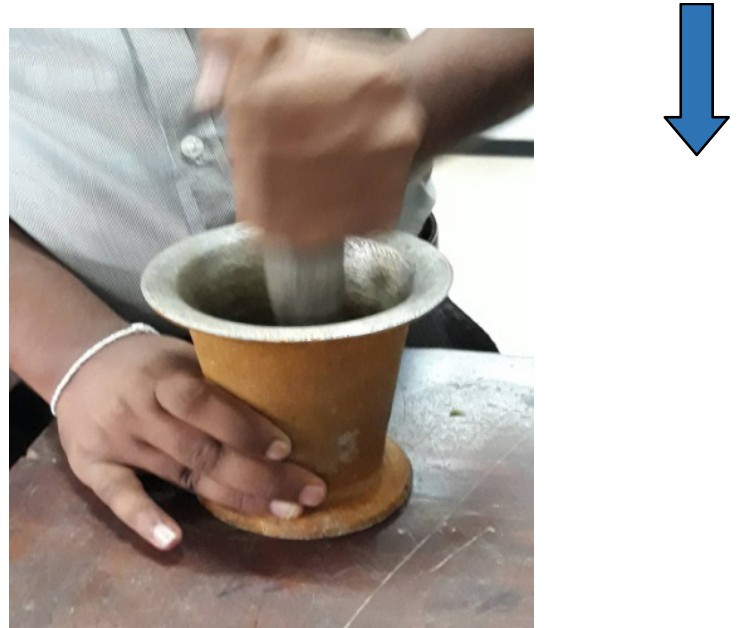

\section{Data Analysis}

Collected data were analyzed using SPSS 22 statistical package.

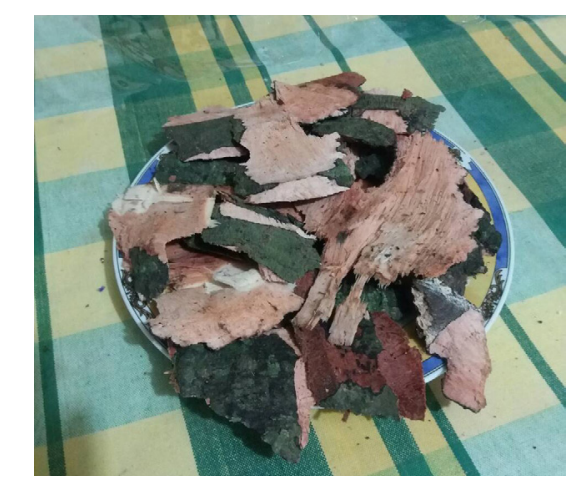
of leaves sap were considered as the test batch and another three khan tubes where the sap was replaced with normal saline was considered as the control batch. Once the blood came to the barrel of the syringe, the stopwatch was switched on. Around $6 \mathrm{ml}$ of blood was collected from each individual, and all the six tubes were quickly filled in separately with $1 \mathrm{ml}$ each. All the six tubes were incubated in a water bath at $37^{\circ} \mathrm{C}$. After five minutes, tubes in both groups were tested carefully for the clots by inclining them slowly up to 45 degrees. Once the clot was seen, the time was taken from the stopwatch (Clotting time). Thus the average clotting time of each particular test and control group was calculated, and the same was done for all the individuals one by one.

Above procedure was repeated to all the fresh juice samples of stem bark and the leaves of Diospyros malabarica.

\section{RESULTS}

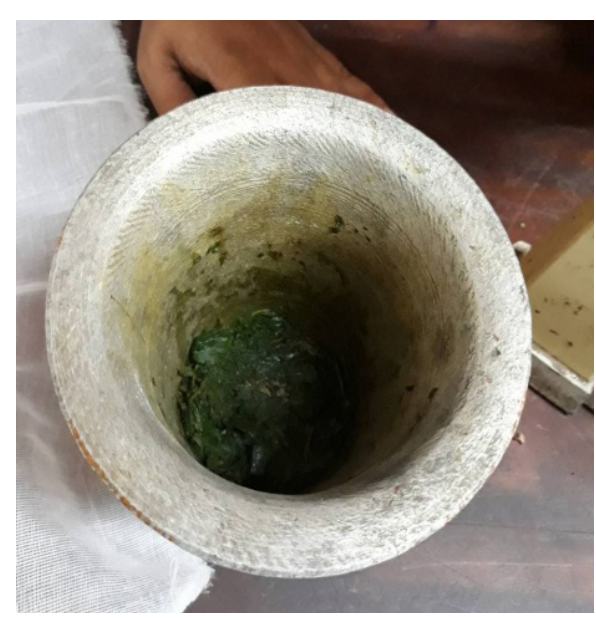

Figure 2 Grinded the leaves and stem bark of Diospyros malabarica 

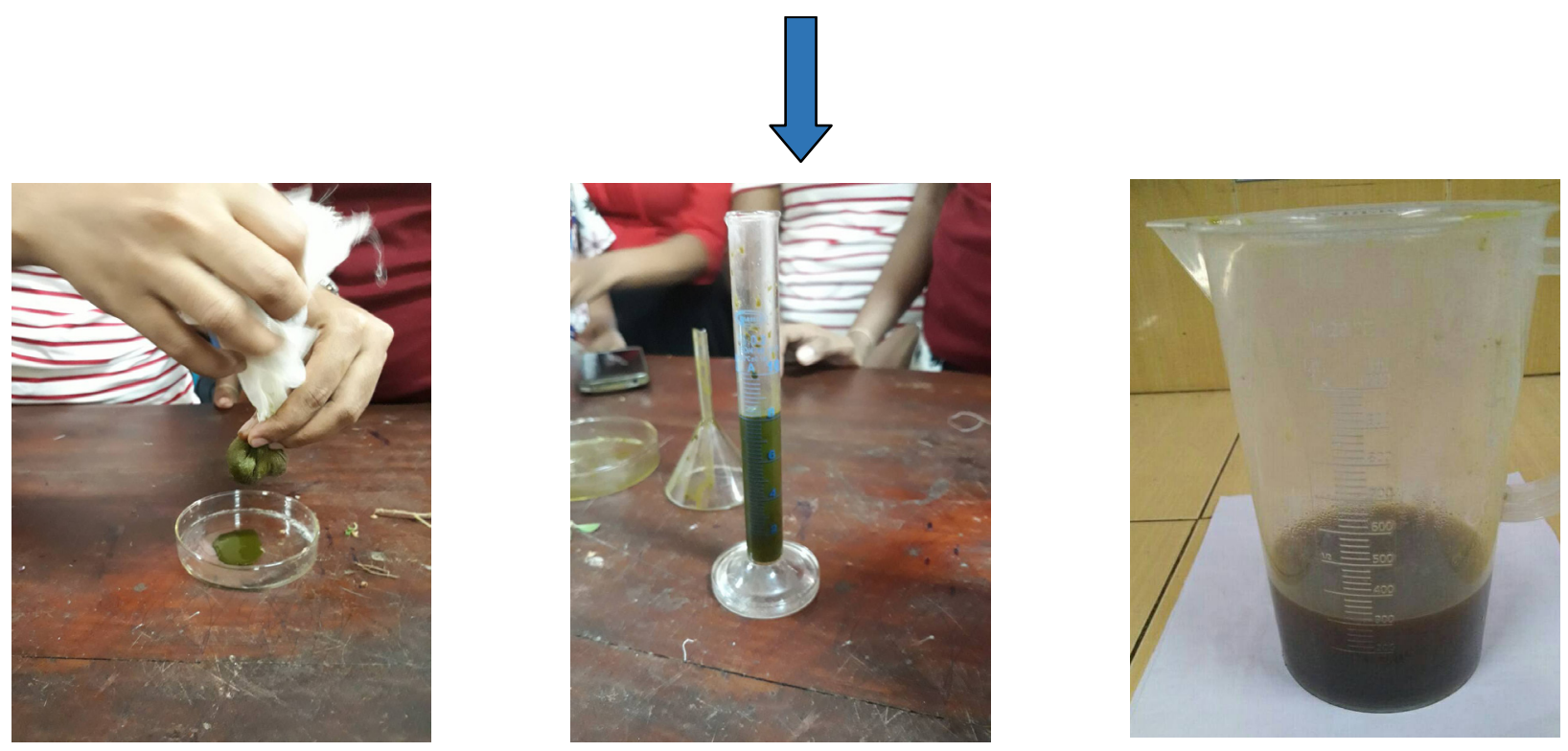

Figure 3 Fresh juice of leaves and stem bark of Diospyros malabarica
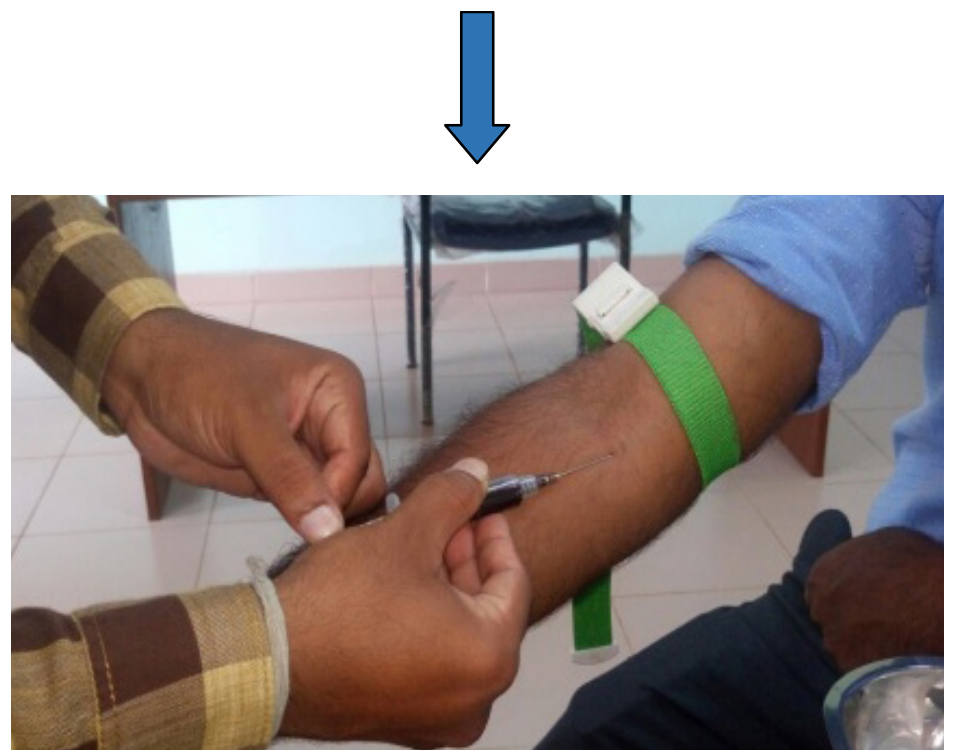

Figure 4 Phlebotomy was done

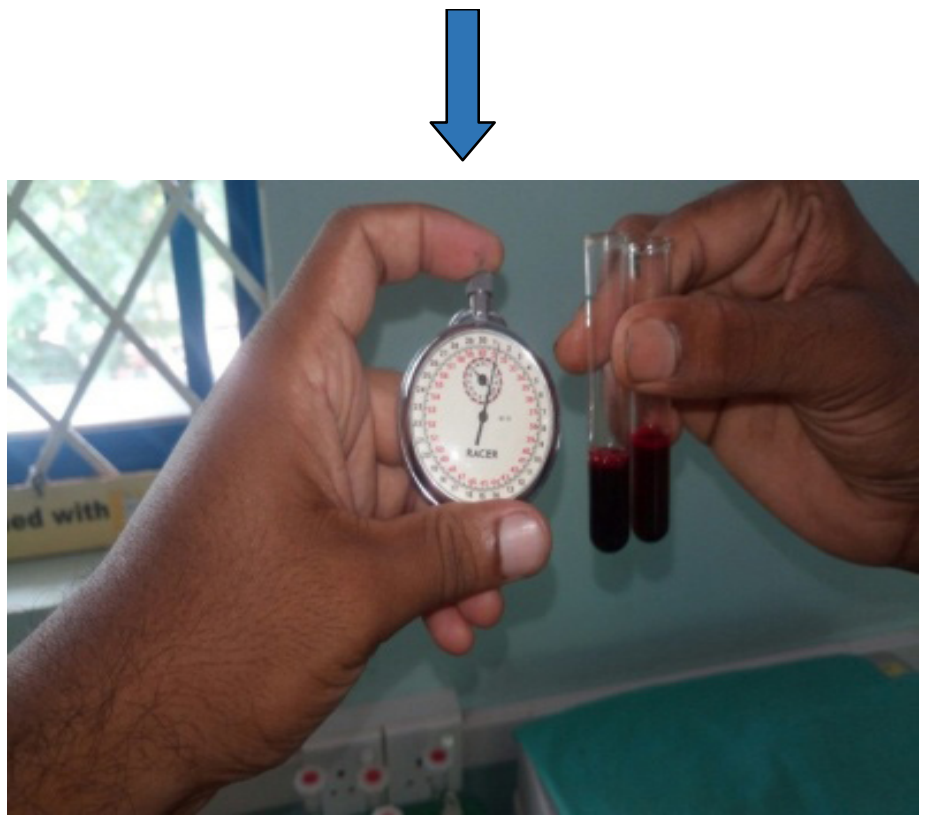

Figure 5 Stopwatch was started simultaneously. 

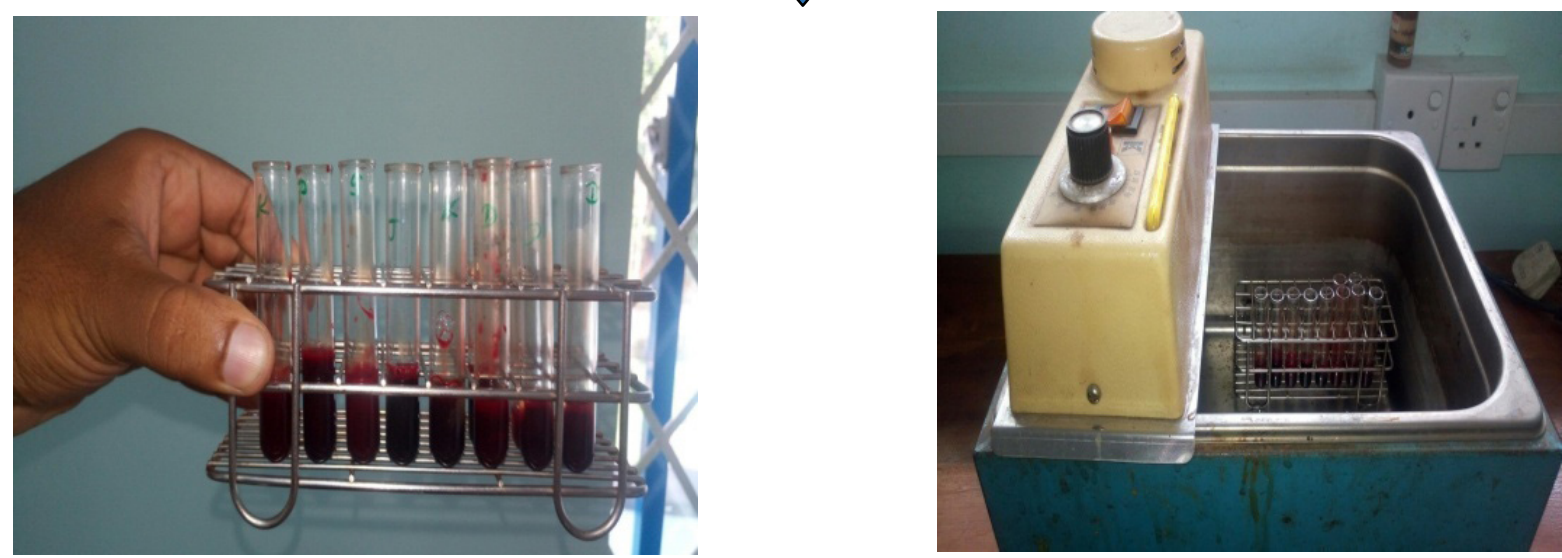

Figure 6 Kept the test tubes on the water bath.

Table 1: Average Clotting time of stem bark of Diospyros malabarica

\begin{tabular}{lll}
\hline $\begin{array}{l}\text { Sample } \\
\text { number }\end{array}$ & $\begin{array}{l}\text { Average clotting } \\
\text { time of the control } \\
\text { group(min) }\end{array}$ & $\begin{array}{l}\text { Average clotting } \\
\text { time of test } \\
\text { group }(\mathrm{min})\end{array}$ \\
\hline 01 & 9.40 & 8.00 \\
02 & 15 & 12.30 \\
03 & 11 & 10.42 \\
04 & 14 & 12 \\
05 & 13.30 & 11.42 \\
06 & 16 & 15.33 \\
07 & 17 & 16 \\
08 & 9.30 & 8 \\
09 & 19.50 & 16 \\
10 & 13.54 & 12 \\
11 & 12.30 & 10 \\
12 & 14 & 11 \\
13 & 12.60 & 9.64 \\
14 & 12 & 11.40 \\
15 & 13 & 12.10 \\
16 & 12 & 10 \\
17 & 11.30 & 9 \\
18 & 14.50 & 12.52 \\
19 & 10 & 8.98 \\
20 & 10.40 & 9 \\
\hline
\end{tabular}

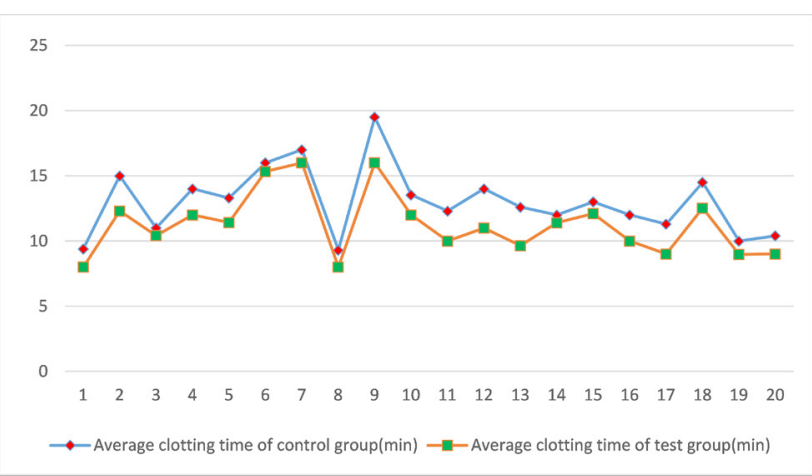

Graph 1: Distribution of average Clotting time of stem bark of Diospyros malabarica
Table 2: Average Clotting time of leaves of Diospyros malabarica

\begin{tabular}{lll}
\hline $\begin{array}{l}\text { Sample } \\
\text { number }\end{array}$ & $\begin{array}{l}\text { Average clotting } \\
\text { time of the control } \\
\text { group(min) }\end{array}$ & $\begin{array}{l}\text { Average clotting } \\
\text { time of test } \\
\text { group }(\mathrm{min})\end{array}$ \\
\hline 01 & 17 & 15 \\
02 & 13.54 & 11.30 \\
03 & 12 & 11 \\
04 & 14.50 & 12 \\
05 & 13 & 12.50 \\
06 & 13.62 & 10 \\
07 & 12.78 & 11 \\
08 & 13 & 10 \\
09 & 9 & 11 \\
10 & 10.60 & 10 \\
11 & 9 & 8.60 \\
12 & 14 & 12.30 \\
13 & 10 & 9.65 \\
14 & 11 & 12.23 \\
15 & 13 & 11.30 \\
16 & 15 & 13 \\
17 & 15.20 & 12 \\
18 & 11.30 & 10.50 \\
19 & 9.30 & 11 \\
20 & 12.50 & 10.67 \\
\hline
\end{tabular}

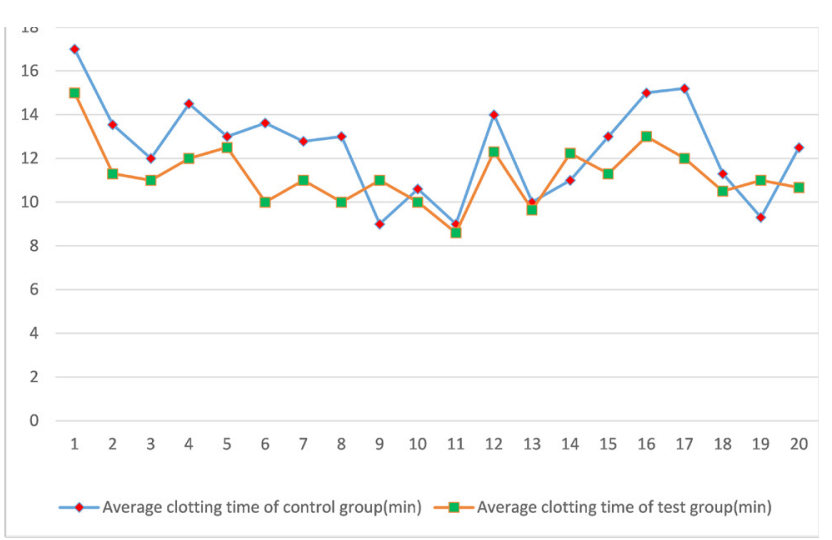

Graph 2: Distribution of average Clotting time of leaves of Diospyros malabarica 
Table 3: Descriptive Statistics for clotting time of stem bark of Diospyros malabarica

\begin{tabular}{lrrrrrrrr}
\hline & \multicolumn{1}{c}{ N } & Range & Minimum & Maximum & \multicolumn{2}{c}{ Mean } & Std. Deviation & Variance \\
\cline { 2 - 9 } & Statistic & Statistic & Statistic & Statistic & Statistic & Std. Error & Statistic & Statistic \\
\hline Control-Stem bark & 20 & 10.20 & 9.30 & 19.50 & 13.0070 & 0.58000 & 2.59382 & 6.728 \\
Test-Stem bark & 20 & 8.00 & 8.00 & 16.00 & 11.2555 & 0.53621 & 2.39799 & 5.750 \\
Valid N (listwise) & 20 & & & & & & & \\
\hline
\end{tabular}

Table 4: Descriptive Statistics for clotting time of stem bark of Diospyros malabarica

Paired Samples Test

\begin{tabular}{|c|c|c|c|c|c|c|c|c|c|}
\hline \multirow[b]{4}{*}{ Mean } & & \\
\hline & & \multicolumn{5}{|c|}{ Paired Differences } & \multirow[b]{3}{*}{$\mathrm{t}$} & \multirow[b]{3}{*}{$\mathrm{df}$} & \multirow{3}{*}{$\begin{array}{l}\text { Sig. } \\
\text { (2-tailed) }\end{array}$} \\
\hline & & \multirow{2}{*}{$\begin{array}{l}\text { Std. } \\
\text { Deviation }\end{array}$} & \multirow{2}{*}{$\begin{array}{l}\text { Std. Error } \\
\text { Mean }\end{array}$} & \multicolumn{2}{|c|}{$\begin{array}{l}95 \% \text { Confidence Interval of } \\
\text { the Difference }\end{array}$} & & & & \\
\hline & & & & Lower & Upper & & & & \\
\hline Pair 1 & $\begin{array}{l}\text { Control-stem bark } \\
\text { Test-stem bark }\end{array}$ & 1.75150 & .85713 & .19166 & 1.35035 & 2.15265 & 9.139 & 19 & .000 \\
\hline
\end{tabular}

Table 6: Descriptive Statistics for clotting time of leaves of Diospyros malabarica

\begin{tabular}{|c|c|c|c|c|c|c|c|c|}
\hline \multirow[b]{3}{*}{ Mean } & \multicolumn{5}{|c|}{ Paired Differences } & \multirow[b]{3}{*}{$\mathrm{t}$} & \multirow[b]{3}{*}{ df } & \multirow{3}{*}{$\begin{array}{l}\text { Sig. } \\
\text { (2-tailed) }\end{array}$} \\
\hline & \multirow{2}{*}{$\begin{array}{l}\text { Std. } \\
\text { Deviation }\end{array}$} & \multirow{2}{*}{$\begin{array}{l}\text { Std. Error } \\
\text { Mean }\end{array}$} & \multicolumn{2}{|c|}{$\begin{array}{l}95 \% \text { Confidence Interval of } \\
\text { the Difference }\end{array}$} & & & & \\
\hline & & & Lower & Upper & & & & \\
\hline $\begin{array}{l}\text { Control-Leaves - } \\
\text { Test-leaves }\end{array}$ & 1.21450 & 1.54485 & .34544 & .49149 & 1.93751 & 3.516 & 19 & .002 \\
\hline
\end{tabular}

Table 5: Descriptive Statistics for clotting time of leaves of Diospyros malabarica

\begin{tabular}{|c|c|c|c|c|c|c|c|c|}
\hline & $N$ & Range & Minimum & Maximum & Mean & & $\begin{array}{l}\text { Std. } \\
\text { deviation }\end{array}$ & Variance \\
\hline & Statistic & Statistic & Statistic & Statistic & Statistic & Std. Error & Statistic & Statistic \\
\hline Control-Leaves & 20 & 8.00 & 9.00 & 17.00 & 12.4670 & 0.49130 & 2.19716 & 4.828 \\
\hline Test-leaves & 20 & 6.40 & 8.60 & 15.00 & 11.2525 & 0.31330 & 1.40111 & 1.963 \\
\hline Valid N (listwise) & 20 & & & & & & & \\
\hline
\end{tabular}

\section{DISCUSSION}

This study carried out to compare the coagulation effect of Diospyros malabarica. The average clotting time of test group of stem bark of Diospyros malabarica (11.25 \pm 2.39 min) was lower than that of control group of stem bark $(13.00 \pm 2.59 \mathrm{~min})$, the situation was statistically highly significant $(\mathrm{p}=0.00, \mathrm{p}<0.05)$.This proves that the stem bark of Diospyros malabarica has a highly significant effect on clotting cascade.

Considering the average clotting time of test group of leaves of Diospyros malabarica (11.25 $\pm 1.40 \mathrm{~min})$ was slightly lower than that of control group of leaves of (12.46 $\pm 2.19 \mathrm{~min}$ ), the situation was also statistically significant $(\mathrm{p}=0.02, \mathrm{p}<0.05)$.

Thus it might imply that there was a possible effect of Diospyros malabarica leaf and stem bark sap on the clotting time. However, some samples of leaves sap, the outcome would become upside down. This could mean that the destruction of ingredients in the leaves sap with the time might have affected the clotting cascade. This could be possible when the sap was opened to the environment for a long time. The oxidation of leaves sap with the time could be the reason for the shift of clotting time of test group from lower to higher.

There are many factors which affect the determination of coagulation time. Rough handling of blood, presence of tissue fluid (traumatic venipuncture), an impurity of extraction, and narrow or unclean tubes will tend to hasten the coagulation time. The extreme temperature of $\mathrm{pH}$ or the use of silicone tubes or paraffine tubes tends to prolonged clotting time.

\section{CONCLUSION}

It is concluded that Diospyros malabarica has got a highly significant coagulating effect in the clotting mechanism. This research has proved that the extract of stem bark and the leaves of Diospyros malabarica have a highly significant effect on clotting cascade. According to the results, the stem bark is the best plant part of Diospyros malabarica, which has Rakthsthambana effect.

\section{REFERENCES}

1 Chandra Amrish; Tarasingh, R. R (2012), Pharmacognostic evaluation of Diospyrosmalabarica bark powder, Asian Journal of Biochemical and Pharmaceutical Research 
Volume: 2 Issue: 1 Pages: 178-185

2 Mondal, Susanta Kumar et al. (2006), In vitro antioxidant activity of Diospyrosmalabarica Kostelbark, Indian journal of experimental biology Volume: 44 Issue: 1 Pages: 39-44.

3 Moorthy. K.R.S. (2006), 6th Edition, Sharangadhara Samhitha, Chaukhambhaorientalia press, Varanasi.

4 Pranjal Sarmah; Debabrat Baishya, (2014), Phytochemical analysis and antioxidant activity of Gardenia jasminoidesellis and Diospyrosmalabarica Kostel, International Journal of Pharma and Bio Sciences Volume: 5 Issue: 1 Pages: P-199-P-204

5 Rode, Mahesh S. et al (2013). Evaluation of anti-diarrheal activity of Diospyros malabarica bark extract. Bangladesh journal of pharmacology. 8(1): 49-53.

6 Trikamji, Jādavaji (2001), CharakaSaṃhitā by Agniveśa Revised by Charaka and Dridhabala with the Ayurveda Dīpika commentary of Chakrapānidatta (Fifth edition), Chaukhambha Sanskrit Sansthan, Varanasi.

7 Trikamji, Jadavji (2002), Sushruta Samhita, Uttara Tantra, 7th Reviseded. Drushtigataroga Adhyaya-7/7-12, Chowkhambha Orientalia, Varanasi.

8 Viswanathan, et al (2002), Chemical constituents of the fruit essential oil of Diospyros malabarica (Desr.) Kostel (Ebenaceae). ActaPharmaceutica (Zagreb). 52 (3):207-211. 